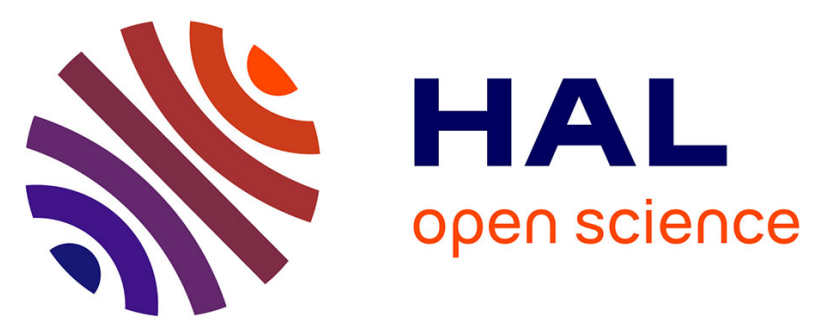

\title{
Late Holocene water level fluctuations of Lake Afourgagh (Middle-Atlas Mountains, Morocco) inferred from charophyte remains
}

\author{
Sébastien Détriché, Jean-Gabriel Bréhéret, I. Soulié-Märsche, L. Karrat, \\ Jean-Jacques Macaire
}

\section{To cite this version:}

Sébastien Détriché, Jean-Gabriel Bréhéret, I. Soulié-Märsche, L. Karrat, Jean-Jacques Macaire. Late Holocene water level fluctuations of Lake Afourgagh (Middle-Atlas Mountains, Morocco) inferred from charophyte remains. Palaeogeography, Palaeoclimatology, Palaeoecology, 2009, 283 (3-4), pp.134-147. 10.1016/j.palaeo.2009.09.012 . insu-00426196

\section{HAL Id: insu-00426196 \\ https://hal-insu.archives-ouvertes.fr/insu-00426196}

Submitted on 14 Mar 2013

HAL is a multi-disciplinary open access archive for the deposit and dissemination of scientific research documents, whether they are published or not. The documents may come from teaching and research institutions in France or abroad, or from public or private research centers.
L'archive ouverte pluridisciplinaire HAL, est destinée au dépôt et à la diffusion de documents scientifiques de niveau recherche, publiés ou non, émanant des établissements d'enseignement et de recherche français ou étrangers, des laboratoires publics ou privés. 


\title{
Late Holocene water level fluctuations of Lake Afourgagh (Middle-Atlas Mountains, Morocco) inferred from charophyte remains
}

- S. Détrichéa

- J.-G. Bréhéret ${ }^{\mathrm{a}}$

- I. Soulié-Märsche

- L. Karrat ${ }^{\mathrm{c}}$

- J.-J. Macaire ${ }^{\mathrm{a}}$

- ${ }^{a}$ Université François-Rabelais de Tours, CNRS/INSU, Université d'Orléans, Institut des Sciences de la Terre d'Orléans - UMR 6113, Laboratoire de géologie, Faculté des Sciences et Techniques, Parc Grandmont, F-37200 Tours, France

- $\quad{ }^{\mathrm{b}}$ UMR CNRS 5554, Paléoenvironnements, Université Montpellier II, Cc 061, Place E. Bataillon, 34095, Montpellier Cedex 5, France

- ${ }^{\mathrm{c}}$ Université Sidi Mohamed Ben Abdellah, Faculté des Sciences Dhar Mahraz Fès, Département de Géologie, Faculté des Sciences de Fès-Atlas, Fès, Morocco

\begin{abstract}
Water level fluctuations of Lake Afourgagh (Middle-Atlas Mountains, Morocco) over the last 2500 years (Late Holocene) have been reconstructed using charophyte remains in the lake sediment archives. The study involved 22 pits (1-3 m deep) dug along a transect across the lake shore terrace. Biogenic activity appears to be a dominant contributor to the accumulation of the lake sediments, as the thickest deposits are tufas composed of charophyte-encrusted stems with numerous gyrogonites (termed "charophyte tufas"). The gyrogonites were identified as Chara aspera and Chara hispida remains. The spatial distribution of these two species, measured vertically within a single core and horizontally along the shore terrace, varies according to bathymetry. Shallow proximal environments are characterized by the development of $C$. aspera, whereas $C$. hispida remains are mostly observed in distal sediments. Moreover, according to their ecological characteristics, the $C$. hispida belt migrated proximally when the water level rose, whereas the $C$. aspera belt migrated distally when the water level fell. These trends were observed successively in a single charophyte tufa layer which records the rise, highstand, and fall of lake level in a single depositional sequence. The late Holocene palaeobathymetry of Lake Afourgagh was inferred by comparing data on charophyte remains and deposit geometry. Data provide evidence for four major low lake level phases (estimated in terms of amplitude) which induced the development of palaeosols in proximal settings at $2191 \mathrm{cal}$. BP, $1769 \mathrm{BP}, 1515 \mathrm{cal}$. BP and $1062 \mathrm{cal}$. BP. These results confirm the accuracy of charophyte-based palaeobathymetry studies.
\end{abstract}

\section{Keywords}

- Palaeolimnology;

- Late Holocene;

- Charophytes; 
- Chara aspera;

- Chara hispida;

- Gyrogonites;

- Karstic lake;

- Middle-Atlas Mountains;

- Morocco

\section{Introduction}

The biotic interactions regulating the sedimentation in shallow lake ecosystems are closely linked to the macrophyte vegetation life cycle. In some cases, charophytes are the main submerged macrophytes in aquatic habitats and can form large meadows in all types of continental waters (García, 1994, Coops and Doef, 1996 and Soulié-Märsche et al., 2002). The major characteristic of these plants is the capacity of the female fructifications to calcify. Through intracellular biomineralisation, many of the species form very typical, spiralled microfossils, termed gyrogonites (Tappan, 1980). Charophyte remains are currently used for paleolimnological reconstructions and are a valuable tool, especially in arid or semi-arid regions (Soulié-Märsche, 1991, Kröpelin and Soulié-Märsche, 1991, Soulié-Märsche, 1993, García, 1994, García and Chivas, 2006, Soulié-Märsche, 2008 and Soulié-Märsche et al., 2008). They can provide information about water depth, salinity, luminosity and chemistry of lakes (Vaidya, 1966, Soulié-Märsche, 1991, García, 1994, Fan et al., 1996, García, 1999, Anadón et al., 2002, Elkhiati et al., 2004, Djamali et al., 2006, García and Chivas, 2006 and Soulié-Märsche, 2008) and can help reconstruct abrupt climate events (SouliéMärsche, 1993).

Lakes of the Moroccan Middle-Atlas Mountains are potential high-resolution recorders of climate events at local scales because they evolve in small catchment areas, and their evolution and sedimentation are directly influenced by local precipitation (Lamb and Van der Kaars, 1995). Depending on climate and anthropogenic activities, the sedimentation rates can reach high values with processes balanced between interactions of detrital inputs, biological activity, and chemical precipitates (Flower et al., 1989, Lamb et al., 1989, Lamb et al., 1991, Flower and Foster, 1992, Benkaddour, 1993, Lamb et al., 1995, Lamb and Van Der Kaars, 1995, Lamb et al., 1999, Détriché, 2007 and Soulié-Märsche et al., 2008).

Lake Afourgagh is a typical example of such an environment as its sedimentation appears to be strongly linked to charophyte production (Détriché et al., 2008). Lacustrine depositional facies and geometry of this lake show a succession of major hydrologic events in the last 2500 years (Détriché et al., 2008). Based on this knowledge, the aim of this study was to characterise the charophyte remains and to use them as proxies to reconstruct fluctuations in lake level during the historical period. We hypothesized that the vertical and horizontal distribution of fossil charophytes in the shore terrace sediments of Lake Afourgagh would help identify palaeohydrological changes. With the same species still growing in similar lakes in the Middle-Atlas Mountains, a direct modern analogy is possible for Lake Afourgagh (Benkaddour, 1993 and Soulié-Märsche et al., 2008).

\section{Site description}

Lake Afourgagh $\left(33^{\circ} 36 \mathrm{~N}, 04^{\circ} 52 \mathrm{~W}\right.$; elevation $\left.1380 \mathrm{~m}\right)$ is a small, shallow permanent lake located in the Middle-Atlas Mountains of Morocco (Fig. 1A). In 2005, the maximum depth of the lake was $\sim 6 \mathrm{~m}$ for a water area of $\sim 3$ ha (Détriché, 2007). The surface water was 
recorded in 1999 as having $\mathrm{pH}$ values of 8 , a conductivity of $900 \mu \mathrm{S} \mathrm{cm}^{-1}$, and a $\mathrm{Mg} / \mathrm{Ca}$ ratio of 8.4 (Gamez et al., 2001). The present day lake is eutrophic to dystrophic with alkaline water and no surface outflow. The present strongly seasonal climate is of a Mediterranean mountain sub-humid type (Rippey, 1982). Winters are wet and controlled by the northwesterly extra-tropical cyclonic storm system moving southward into Western Europe and the Mediterranean, whereas summers are dry, resulting from the extension of the North Atlantic subtropical high pressure cell into north-western Africa (Lamb and Peppler,

1991 and Cheddadi et al., 1998). Mean annual precipitation in the area is $\sim 700 \mathrm{~mm}$, most of which falls between October and April (Bentayeb and Leclerc, 1977 and Rippey, 1982); mean annual air temperature is $12{ }^{\circ} \mathrm{C}$ with a minimum of $\sim-4{ }^{\circ} \mathrm{C}$ (snow may persist for several weeks) and a maximum of $\sim 35^{\circ} \mathrm{C}$ (Baali, 1998). The lake catchment is mainly composed of strongly karstified Lower Lias dolomites, Middle Lias limestones, superficial Plio-Quaternary conglomerates, and alluvial fan clays and silts (Fig. 1B) (Martin, 1981 and Baali, 1998). Lake Afourgagh is a karstic groundwater-fed lake which is moderately supplied with runoff, snow melt, and occasional thunderstorm-induced sheetfloods. The maximum extension of the shoreline coincides with some scars (presence of wave-cut notches) of a lake stabilisation level corresponding to that of the lake outflow through a wadi ("Oued Afourgagh") which was still fed in 1996 (Baali, 1998). The lake is closed today due to successive droughts and more particularly to human activities since the early 1970s (Amyay et al., 2001). 


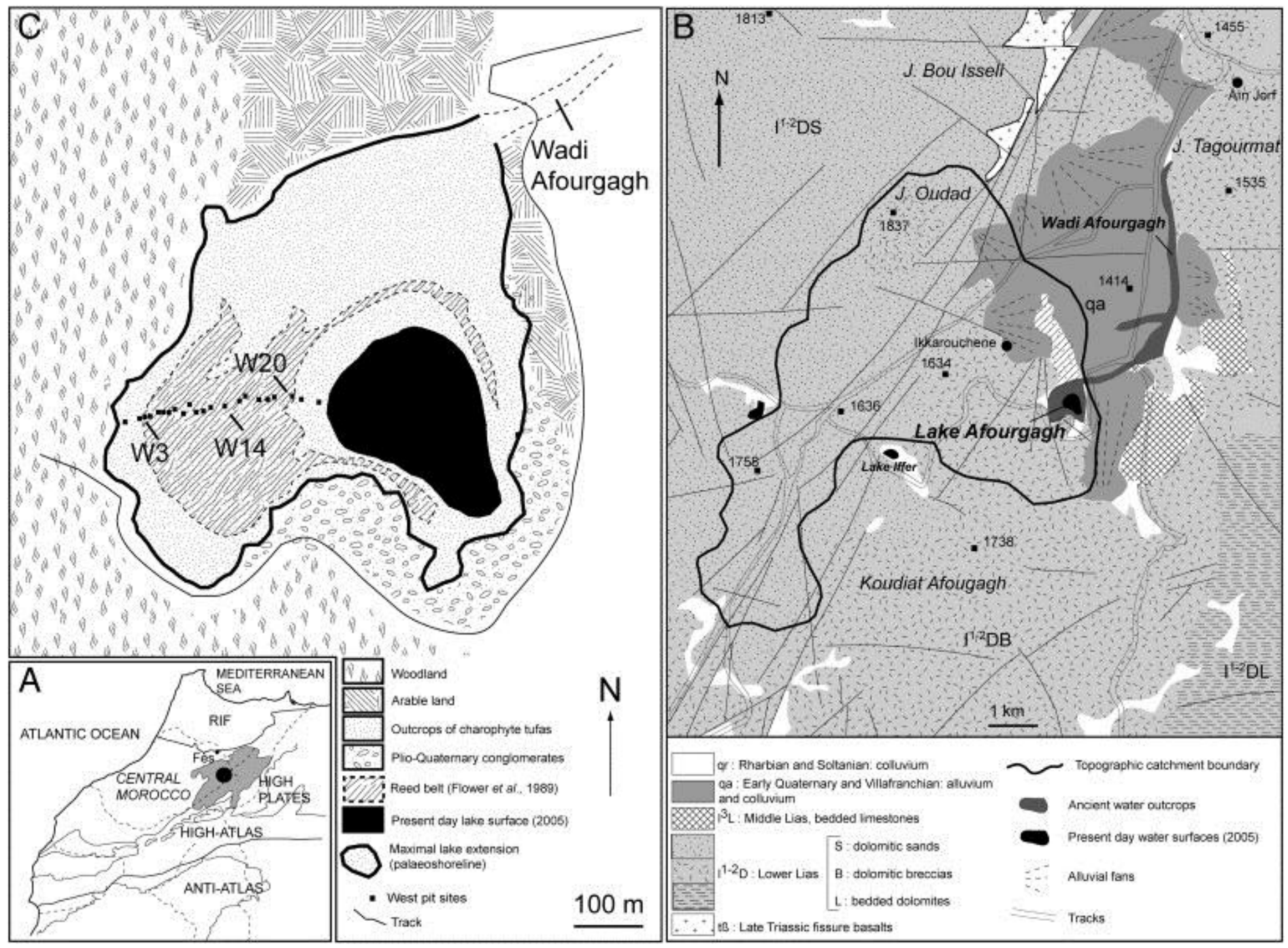

Fig. 1. A - Location of Lake Afourgagh. B - Geology of the Lake Afourgagh topographic catchment (Charrière, 1990). C - Present day environment of Lake Afourgagh, comprising the 2005 (summer) lake extension, the palaeo-shoreline position, and location of the west transect pits.

Most of the land around lake Afourgagh (47\% of the catchment area) supports severely degraded forests with Quercus rotundifolia and occasional Juniperus phoenicea, Pinus pinaster, and $P$. halepensis, although $44 \%$ is occupied by cultivated fields and pastureland ( Flower et al., 1989, Lamb et al., 1991 and Chillasse et al., 2001). Hydrophytes consist of Ranunculus millifoliatus, Polygonum amphibium, Myriophyllum spicatum, and occasional Chara aspera ( Morgan, 1982 and Chillasse et al., 2001). Helophytes previously consisted of Typha sp. and Phragmites communis, but this reed belt, which was still in good shape in 1984, has since been cut down by the local population ( Morgan, 1982, Flower et al., 1989 and Chillasse et al., 2001). 


\section{Materials and methods}

\subsection{Field survey and facies description}

A 323-metre-long transect, comprising 22 pits (1-3 m deep), was dug down to the substratum along the shore terrace directly west of the present day lake (Fig. 1C). The maximum thickness of the lacustrine sediments above the substratum was $3.3 \mathrm{~m}$. The lacustrine succession comprises alternations of three main facies (Table 1). The first facies is composed of dark brown, compact, centimetre- to decimetre-thick layers, interpreted as ancient soils, termed "palaeosols", in the proximal area. The second facies contains palustrine silts, distally transgressive on the palaeosols. The third facies is defined by centimetre- to decimetre-thick layers of porous carbonates composed of accumulations of encrusted stems of charophytes interbedded with $\mathrm{cm}$-scale beds of silty mudstones. These crumbly sediments overlie the basal body (substratum) consisting of brown to reddish silty-clayey deposits, interpreted as alluvial fan deposits (Baali, 1998). The alluvial fan layer is several metres thick and was found in all the pits, serving as a datum level for correlation purposes. Below the datum layer, a grey muddy siltstone acts as the local aquifer. Détriché et al. (2008) provided a detailed description of the sedimentary units (A-E) and sub-units as well as the correlation among the 22 pits. The present study focuses on six pits distributed from the proximal to the distal area perpendicular to the shoreline: W3, W6, W10, W14, W18 and W20 (Fig. 1C). Samples were taken from all three facies types. Sample notation includes the pit number reference followed by the sample number reference, e.g. W20-5 (pit W20, sample no. 5). 
Table 1. Summary of the characteristics of the three main facies and their relationship to the different sequences and sedimentary sub-units. Adapted from Détriché et al. (2008, Fig. 3).

\begin{tabular}{|c|c|c|}
\hline Facies type & \multicolumn{2}{|r|}{ Main characteristics } \\
\hline \multirow{6}{*}{$\begin{array}{l}\text { Charophyte tufas } \\
\text { (T) }\end{array}$} & \multirow{3}{*}{ Lithofacies } & Silty to sandy grain size, mostly carbonated (carbonate content up to $96 \%$ ), few detrital particles \\
\hline & & Accumulation of charophyte remains \\
\hline & & $\begin{array}{l}\text { Various preservation degrees from proximal (compacted, poorly preserved) to distal (porous, } \\
\text { well-preserved) areas }\end{array}$ \\
\hline & \multirow{2}{*}{ Biofacies } & Charophyte remains: gyrogonites, encrusted stems, oospores \\
\hline & & Ostracods and aquatic molluscs \\
\hline & Structures & $\begin{array}{l}\text { Laminated in distal area (alternance of silty-clayey detrital laminae and carbonated charophyte } \\
\text { tufa laminae) }\end{array}$ \\
\hline \multirow{5}{*}{$\begin{array}{l}\text { Palustrine silts } \\
\text { (PS) }\end{array}$} & Lithofacies & $\begin{array}{l}\text { Silty-clayey grain size, mix of detrital, carbonated and very well-preserved organic particles } \\
\text { TOC } \sim 5 \%\end{array}$ \\
\hline & \multirow{3}{*}{ Biofacies } & Numerous ostracods, aquatic molluscs and diatom remains \\
\hline & & Lot of very well-preserved macrophyte remnants and sponge spicules \\
\hline & & Poorly preserved charophyte-encrusted stems, gyrogonites and oospores \\
\hline & Structures & Bedded to laminated in sub-unit $\mathrm{Al}$ in distal area \\
\hline \multirow{5}{*}{ Palaeosols (P) } & Lithofacies & $\begin{array}{l}\text { Sandy to silty grain size, mix of detrital, carbonated and organic particles } \\
\text { TOC }>5 \%\end{array}$ \\
\hline & \multirow{3}{*}{ Biofacies } & Ostracods, terrestrial and aquatic molluscs, diatoms, insect remains \\
\hline & & Few poorly preserved charophyte-encrusted stems, gyrogonites and oospores \\
\hline & & Roots and organic excretas \\
\hline & Structures & Lumpy texture \\
\hline \multicolumn{3}{|c|}{ Sequences (Units) Sub-units (facies type) } \\
\hline \multirow[t]{2}{*}{ (E) } & E (soil) & \\
\hline & $\mathrm{D} 2(\mathrm{~T})$ & \\
\hline \multirow[t]{2}{*}{ S4 (D) } & D1' (PS) & \\
\hline & $\mathrm{D} 1(\mathrm{P})$ & \\
\hline \multirow{2}{*}{ S3 (C) } & $\mathrm{C} 2(\mathrm{~T})$ & \\
\hline & CI (PS) & \\
\hline \multirow{3}{*}{ S2 (B) } & $\mathrm{B} 2(\mathrm{~T})$ & \\
\hline & $\mathrm{B} 1^{\prime}(\mathrm{PS})$ & \\
\hline & $\mathrm{B} 1(\mathrm{P})$ & \\
\hline \multirow{7}{*}{ SI (A) } & A7 (T) & \\
\hline & A6 (T) & \\
\hline & A5 (T) & \\
\hline & $\mathrm{A} 4(\mathrm{~T})$ & \\
\hline & $\mathrm{A} 3(\mathrm{~T})$ & \\
\hline & $\mathrm{A} 2(\mathrm{~T}+\mathrm{PS})$ & \\
\hline & $\mathrm{Al}$ (PS) & \\
\hline
\end{tabular}

\subsection{Radiocarbon chronology}

Nine radiocarbon ages measured on total organic matter were obtained by conventional (Laboratoire des Sciences du Climat et de l'Environnement, LSCE CNRS Gif-sur-Yvette, France) and AMS (Accelerator Mass Spectrometry Laboratory, Tucson, Arizona, United States) methods (Table 2). The samples consisted of a mixture of charcoal and terrestrial and aquatic plant remains. However, old carbon, frequent in karstic lake environments, can easily contaminate samples of dated palustrine silts and palaeosols. To avoid this problem, the chronological model was constructed using data with low $\delta^{13} \mathrm{C}$ values, testifying to the 
dominance of terrestrial remains and charcoals in the dated material. $\mathrm{All}{ }^{14} \mathrm{C}$ ages were calibrated using Calib 5.1 (Stuiver and Reimer, 1993; data set from Stuiver et al., 1998). The radiocarbon ages were used to construct a 2500 year calibrated age chronology using continuous and discontinuous models (Fig. 2). 
Table 2. Radiocarbon ages obtained on total organics and median calibrated and calendar ages $(+/-2 \sigma)$. Depths from topographic surface are given for pit W20.

\begin{tabular}{|c|c|c|c|c|c|c|c|}
\hline $\begin{array}{l}\text { Laboratory } \\
\text { code }\end{array}$ & $\begin{array}{l}\text { Sample } \\
\text { reference }\end{array}$ & Method & $\begin{array}{c}\text { Conventional } \\
\text { radiocarbon age } \\
\text { yrs BP }\end{array}$ & $\begin{array}{c}\text { Median } \\
\text { calibrated age } \\
(+/-2 \sigma) \text { yrs BP }\end{array}$ & $\begin{array}{c}\text { Median calendar } \\
\text { age }(+/-2 \sigma) \text { yrs } \\
\text { BC/AD }\end{array}$ & $\begin{array}{c}\text { Depth from } \\
\text { topographic } \\
\text { surface in pit W20 } \\
\text { (m) }\end{array}$ & $\begin{array}{c}\text { Delta } \\
{ }^{13} \mathrm{C}(\%)\end{array}$ \\
\hline Gif-11955 & W14-4 & Conventional & $490 \pm 35$ & $525(553-496)$ & $\begin{array}{l}1426 \mathrm{AD} \\
(1397 \mathrm{AD}- \\
1454 \mathrm{AD})\end{array}$ & 0.65 & -28.75 \\
\hline Gif-12191 & W3-3 & Conventional & $810 \pm 50$ & 739 (798-666) & $\begin{array}{l}1218 \mathrm{AD} \\
(1152 \mathrm{AD}- \\
1284 \mathrm{AD})\end{array}$ & 0.65 & -26.87 \\
\hline Gif-12190 & W3-5-1 & Conventional & $1125 \pm 45$ & $\begin{array}{l}1050(1146- \\
953)\end{array}$ & $\begin{array}{l}901 \mathrm{AD} \\
(804 \mathrm{AD}- \\
997 \mathrm{AD})\end{array}$ & 0.75 & -26.8 \\
\hline SacA 7404 & W2Obis-15 & AMS & $1150 \pm 30$ & $\begin{array}{l}1062(1146- \\
977)\end{array}$ & $\begin{array}{l}689 \mathrm{AD} \\
(804 \mathrm{AD}- \\
573 \mathrm{AD})\end{array}$ & 0.75 & -29.05 \\
\hline Gif-12192 & W12-6 & Conventional & $1640 \pm 35$ & $\begin{array}{l}1515(1615- \\
1415)\end{array}$ & $\begin{array}{l}435 \mathrm{AD} \\
(335 \mathrm{AD}- \\
535 \mathrm{AD})\end{array}$ & 1.3 & -27.2 \\
\hline Gif-11953 & W14-9 & Conventional & $1910 \pm 30$ & $\begin{array}{l}1869(1929- \\
1809)\end{array}$ & $\begin{array}{l}81 \mathrm{AD}(21 \mathrm{AD}- \\
141 \mathrm{AD})\end{array}$ & 1.46 & -1.42 \\
\hline Gif-12188 & W20-17 & Conventional & $1915 \pm 35$ & $\begin{array}{l}1861(1946- \\
1775)\end{array}$ & $\begin{array}{l}90 \mathrm{AD}(4 \mathrm{AD}- \\
175 \mathrm{AD})\end{array}$ & 2.6 & -32.07 \\
\hline A-14039 & W20-20 & AMS & $2175 \pm 45$ & $\begin{array}{l}2191(2327- \\
2055)\end{array}$ & $\begin{array}{l}242 \mathrm{BC} \mathrm{(}(378 \mathrm{BC}- \\
106 \mathrm{BC})\end{array}$ & 3 & -25.6 \\
\hline Gif-11951 & W14-15 & AMS & $2365 \pm 50$ & $\begin{array}{l}2426(2541- \\
2310)\end{array}$ & $\begin{array}{l}477 \mathrm{BC}(592 \mathrm{BC}- \\
361 \mathrm{BC})\end{array}$ & 3.2 & -3.71 \\
\hline
\end{tabular}




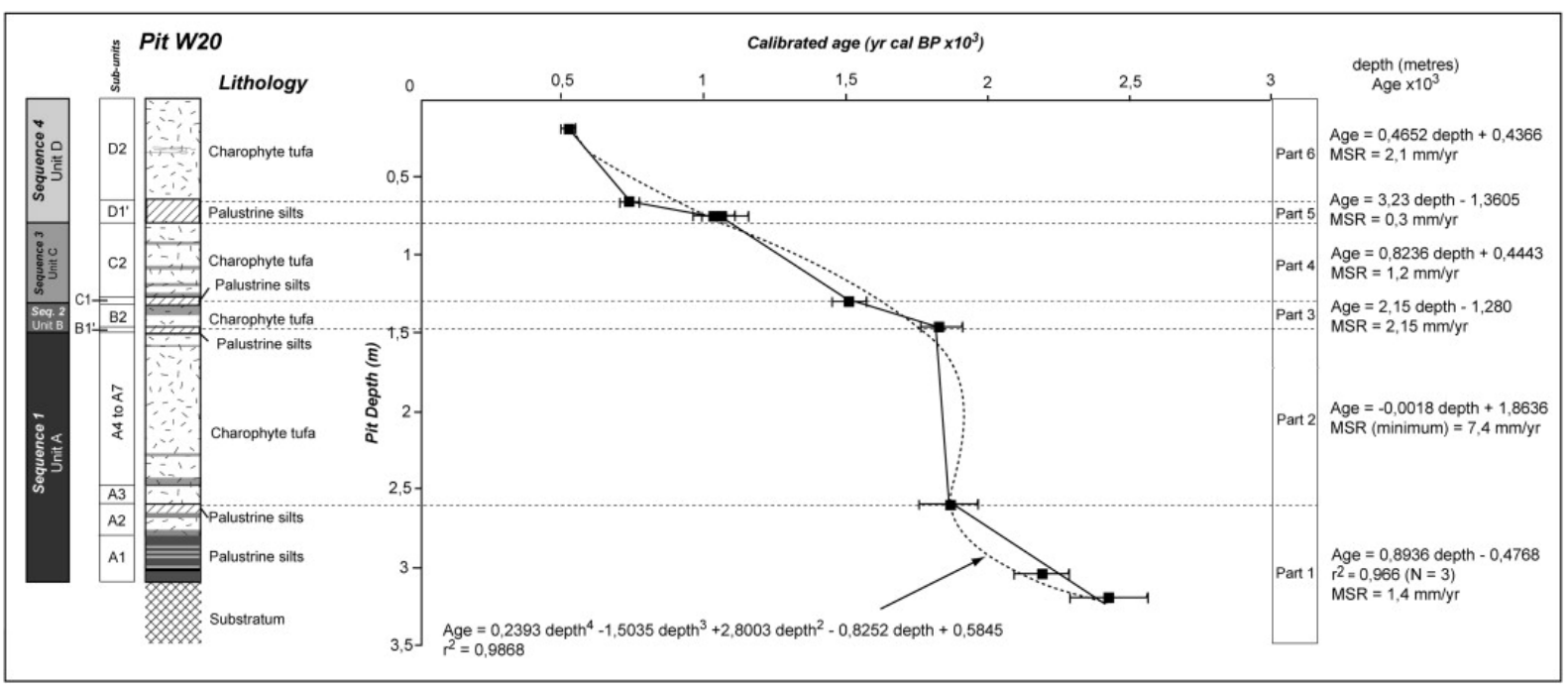

Fig. 2. Synthetic description of pit W20 (lithology, sequences and sedimentary unit and subunit boundaries), and age-depth relationship. For each domain (Parts) of assumed constant sedimentation rates, the age (cal. years $\left.\mathrm{BP} / 10^{3}\right)=f($ depth $\left.)(\mathrm{m})\right)$ function is given with the mean sedimentation rate (MSR).

The nine radiocarbon ages were obtained from four different pits (W3, W12, W14 and W20). To determine the age-depth relationship, the three main facies in the study area were correlated (using regular facies alternations and trenches between pits, Fig. 3). All radiocarbon data could then be referenced against the depth scale of the W20 pit which provided a continuous record of deposits and showed the lowest degree of compaction. Care had to be taken, because charophyte tufa sub-unit thicknesses are greatly constrained by bioinduced production of charophyte carbonate and accumulation of charophyte remains, which are directly linked to charophyte colonization (meadow density) and environmental fluctuations. Moreover, charophyte tufas are composed of a fragile pile-up of encrusted charophyte stems, which are highly prone to compaction, particularly in median and proximal areas. This compaction can considerably reduce the thickness of charophyte tufas. Thus, sedimentation rate values are maximum estimations and are largely counter-balanced by charophyte colonization and bioinduced carbonate production. 


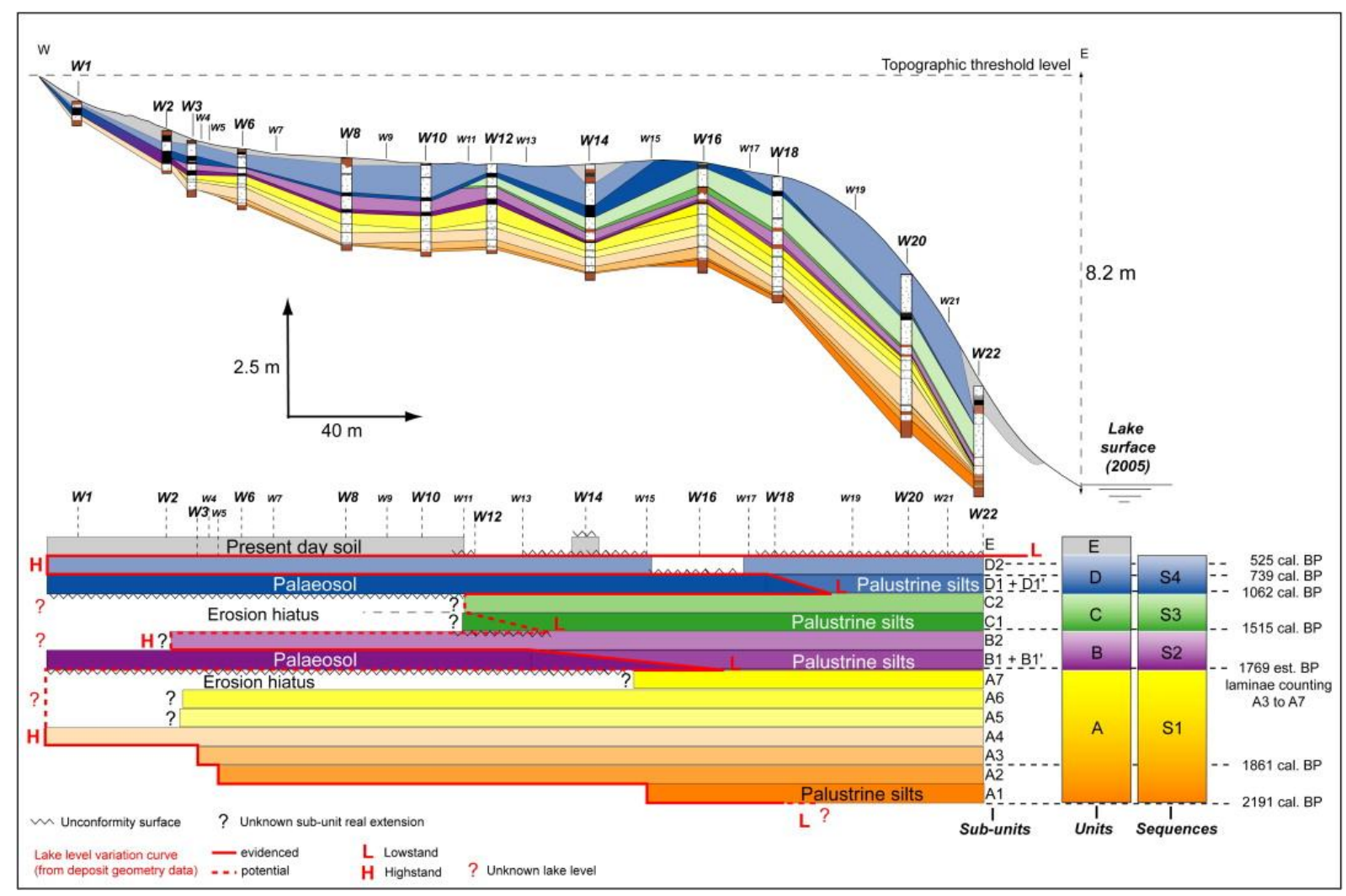

Fig. 3. Deposit geometry along the west transect and definition of sequences, sedimentary units and sub-units deduced from correlations between pits and facies alternations (see Table 1 for correspondences between facies and sedimentary sub-units). The lateral extension of the different sub-units between the W22 pit and the palaeo-shoreline is used to make a simple chronogram (constant time step) in order to provide evidence for the presence of erosion hiatuses and to reconstruct a lake level variation curve of the last 2000 years.

No polynomial continuous model was able to reproduce the ${ }^{14} \mathrm{C}$ age distribution, because the sedimentation rates showed strong variations between charophyte tufa layers (up to more than $7 \mathrm{~mm} / \mathrm{yr}$ ) and organic/silty beds (less than $1 \mathrm{~mm} / \mathrm{yr}$ ). As a consequence, a discontinuous model was used, assuming constant sedimentation rates in six domains with boundaries corresponding to those between charophyte tufas and silts. The age-depth model was constructed by fitting six linear regression curves to the different chronological points. Even though the disputable five domains (see Fig. 2) contain only two points, the discontinuous model undoubtedly reflects the dynamics of deposits better than the continuous model.

Although they are separated by a thick layer, the sub-units A2 and B1 present similar ages. This is the consequence of an overlap of radiocarbon data uncertainties, while the sedimentation rate is rather high. Tufa laminae were therefore counted (unit A, Fig. 3) based on the assumption of a highly probable seasonal rhythm. With a total of 92 layers, corresponding to approximately one hundred years of deposition, the age of B1' (sample W14-9) was estimated as ca. 1769 BP.

\subsection{Depositional facies and geometry data}

Sedimentary facies and geometry of the deposits were previously used by Détriché et al. (2008) to infer the lake level fluctuations over the last 2500 years (Fig. 2 and Fig. 3, Table 1). 
Palaeosols were attributed to low lake level phases with prolonged emersion of the proximal area. Palustrine silts, composed of a mix of macrophyte remains and detrital silts, which are distally transgressive on palaeosols, were correlated with rising water level phases. Tufas were attributed to high lake level phases. The geometry of sediments showed the presence of four depositional sequences (S1 to S4) corresponding to four sedimentary units (A to D) divided into sub-units based on (1) facies alternations, and (2) lateral extension of sub-units along the shore terrace perpendicular to the shoreline (A1, A2 ...D1', D2, Fig. 3). Each depositional sequence was defined by sediments attributed to the fall of lake level and a lowstand episode, followed by a rise in lake level and a highstand episode. The four sequences were determined as follows:

Sequence 1 (Unit A, 2191 cal. BP - 1769 BP est.) corresponds to (1) a transgressive phase with a rise in water level (sub-units A1 to A4) up to the topographic threshold level, followed by (2) an aggradation phase (sub-units A5 to A7);

Sequence 2 (Unit B, 1769 BP est. - 1515 cal. BP) shows a regressive phase with the development of the proximal palaeosol (sub-unit B1) and the palustrine silts (sub-unit $\mathrm{B} 1^{\prime}$ ) in its distal extension. With the rise in water level (below the topographic threshold level), the palaeosol was covered with silts (transgression), and when the environment became favourable (stabilised), the development of the charophyte meadow led to the formation of charophyte tufa (sub-unit B2).

Sequence 3 (Unit C, 1515 cal. BP - $1050 \mathrm{cal}$. BP) begins with the formation of a proximal palaeosol on prior sediments (erosion hiatus or proximal mixing with subunit B1 as a result of compaction) and distal palustrine silts (sub-unit $\mathrm{C} 1$ ). As in Sequence 2, silts are overlain by charophyte tufas (sub-unit C2) testifying to a rise in water level (but not to the level of the topographic threshold).

Sequence 4 (Unit D, 1050 cal. BP — present day) records the same behaviour as Sequence 2 with the formation of an extended palaeosol (sub-unit D1) during a lowstand phase followed by a rise in water level to the topographic threshold, illustrated by the deposition of transgressive palustrine silts (sub-unit D1') and the subsequent accumulation of charophyte tufas (sub-unit D2). Unit E corresponds to the present day lowstand, essentially induced by human activities.

The succession of depositional sequences testifies to abrupt environmental changes during the historical period. Using only this stratigraphic data, a curve of lake level variations over the last 2500 years was reconstructed (Fig. 3). However, due to several erosion hiatuses, the amplitude of some highstand and lowstand phases remained unknown. Charophyte data were thus used to provide the missing information.

\subsection{Charophyte sampling}

Charophyte analyses were undertaken on all samples from five pits: W3, W6, W10, W14, and W20. All facies were sampled but no fine sampling step was included, as the aim of the study was to follow the general lateral and vertical evolution of species repartition based on facies distribution. Charophyte remains were recovered by washing and sieving previously dried sediments (500, 250, and $125 \mu \mathrm{m}$ meshes). Three fossil types were identified: (1) calcified vegetative parts - remains of the genus Chara showing variable degrees of preservation, (2) original oospores, composed of organic matter, corresponding to the fertilized female 
reproductive organ, and (3) calcified oospores called gyrogonites with species-specific characteristics (Soulié-Märsche, 1989). One hundred gyrogonites taken from two of the richest charophyte tufa samples (W10-15 and W6-4) were measured for statistical analysis with a Leitz micrometric screw to determine the charophyte species. Parameters described by Horn af Rantzien (1956) were measured, i.e. the largest polar axis (Length), the largest equatorial diameter (Width), and the isopolarity index (ISI $=$ Length $\times 100 /$ Width $)$. Data from Horn af Rantzien, 1959, Soulié-Märsche, 1989 and Krause, 1997 were used as references for the systematic identification.

\section{Results}

\subsection{Charophyte remains, species identification, and ecological characteristics}

The most widely occurring deposits are charophyte tufas, particularly in the distal area where they can be up to a metre thick. "Tufas" contain carbonate-encrusted stems with charophyte gyrogonites and oospores in variable states of preservation. Present day charophytes in Lake Afourgagh, collected by the authors in 2005, only consisted of scattered Chara aspera Detharding ex Willdenow stands. Indeed, eutrophication and increasing turbidity observed in present day Lake Afourgagh has led to the disappearance of these macrophyte populations ( Kohler et al., 1971 and Scheffer et al., 1993).

The biometric analysis of different samples of gyrogonites clearly differentiates between two clusters on the basis of their length and width: (1) small gyrogonites (W10-15, average $630 \times 380 \mu \mathrm{m}$ ), and (2) large gyrogonites (W6-4, average $900 \times 600 \mu \mathrm{m})$ (Fig. 4 and Table 3). The morphology and dimensions of the specimens from sample W10-15 resemble closely those of Chara aspera (Detharding ex Willdenow), a relatively common taxon in the Moroccan Middle-Atlas Mountains ( Feldmann, 1953 and Morgan, 1982). There may also be a few scattered gyrogonites of Chara vulgaris Linné (less than 3\%) by comparison with the morphometrical results of Soulié-Märsche, 1989 and Djamali et al., 2006. The fructifications of this species are very similar to Chara aspera, but are wider and less elongated. The measurements of sample W6-4 show a larger distribution window with typical morphology of the gyrogonites of Chara hispida Linné. A few gyrogonites of Chara globularis Thuillier (only 2\%), characterised by an apical rosette, were also found (Fig. 5). Both species $(C$. hispida and C. globularis) are also found in lakes of the Middle-Atlas Mountains ( Feldmann, 1953, Morgan, 1982 and Benkaddour, 1993). The few gyrogonites of the ubiquitous $C$. globularis and $C$. vulgaris are less helpful for defining specific environments, so only $C$. aspera and C. hispida gyrogonites are used as proxies for palaeoenvironmental reconstructions. In addition, the very well-preserved encrusted stems of charophytes may indicate in situ preservation. 


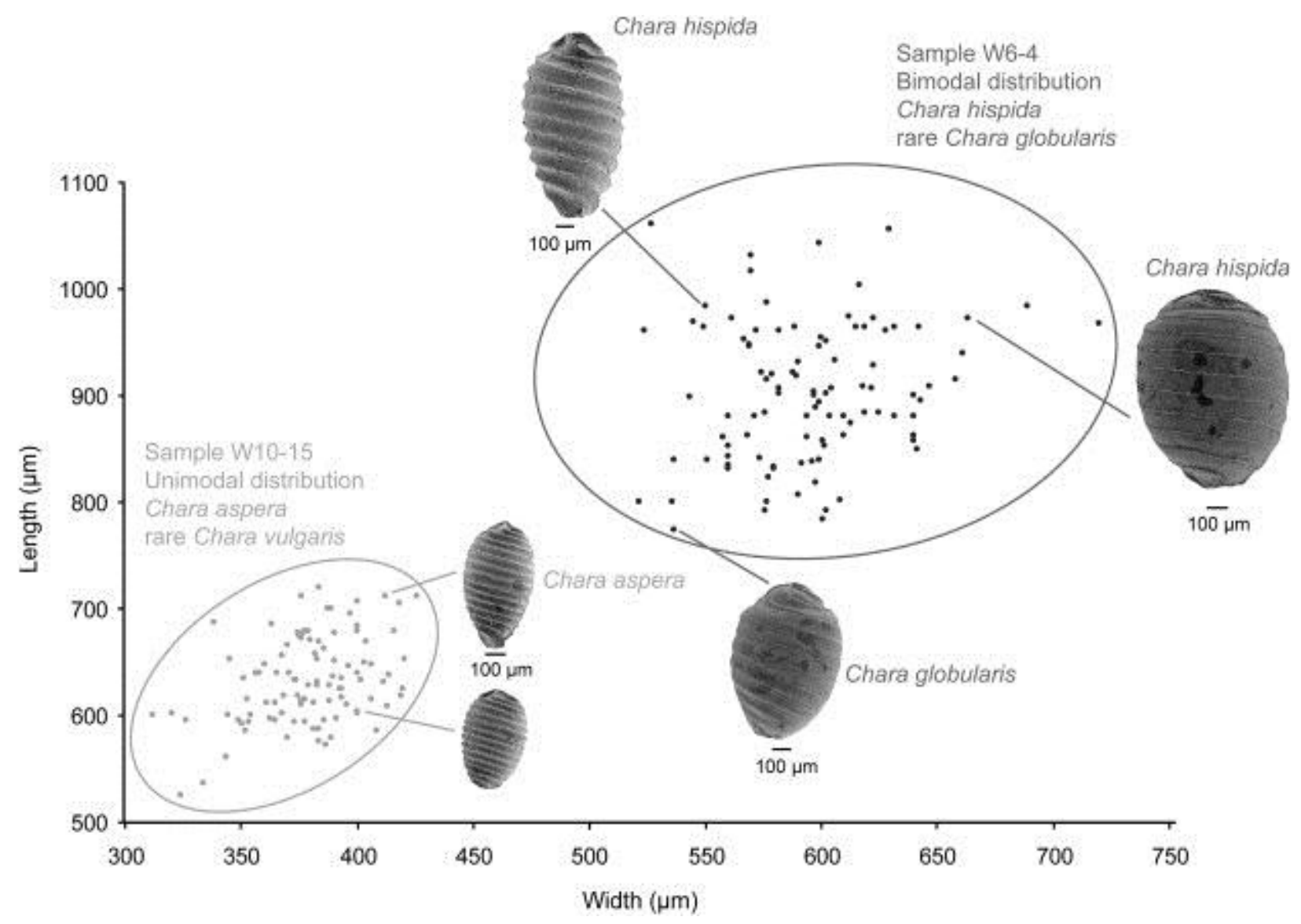

Fig. 4. Distribution graph of length and width measured on 100 gyrogonites of samples W10-15 and W6-4 with species examples. 
Table 3. Biometric data of gyrogonites from samples W10-15 and W6-4 (number of measurements is 100 for each sample).

\section{Length (L) $\mu \mathrm{m}$ Width (W) $\mu \mathrm{m}$ Isopolarity index ISI}

Sample W1O-15: Chara aspera

$\begin{array}{llll}\text { Min } & 524 & 312 & 143 \\ \text { Max } & 720 & 426 & 203 \\ \text { Mean } & 632 & 379 & 167 \\ \text { Confidence interval } & 624-640 & 375-384 & 165-169 \\ \sigma^{2} & 1639 & 554 & 136 \\ \mathrm{~V}(\%) & 6 & 6 & 7\end{array}$

Sample W6-4: Chara hispida

$\begin{array}{llll}\text { Min } & 774 & 522 & 130 \\ \text { Max } & 1060 & 720 & 201 \\ \text { Mean } & 901 & 594 & 152 \\ \text { Confidence interval } & 888-913 & 587-601 & 149-154 \\ \sigma^{2} & 4177 & 1258 & 169 \\ \text { V }(\%) & 7 & 6 & 9\end{array}$




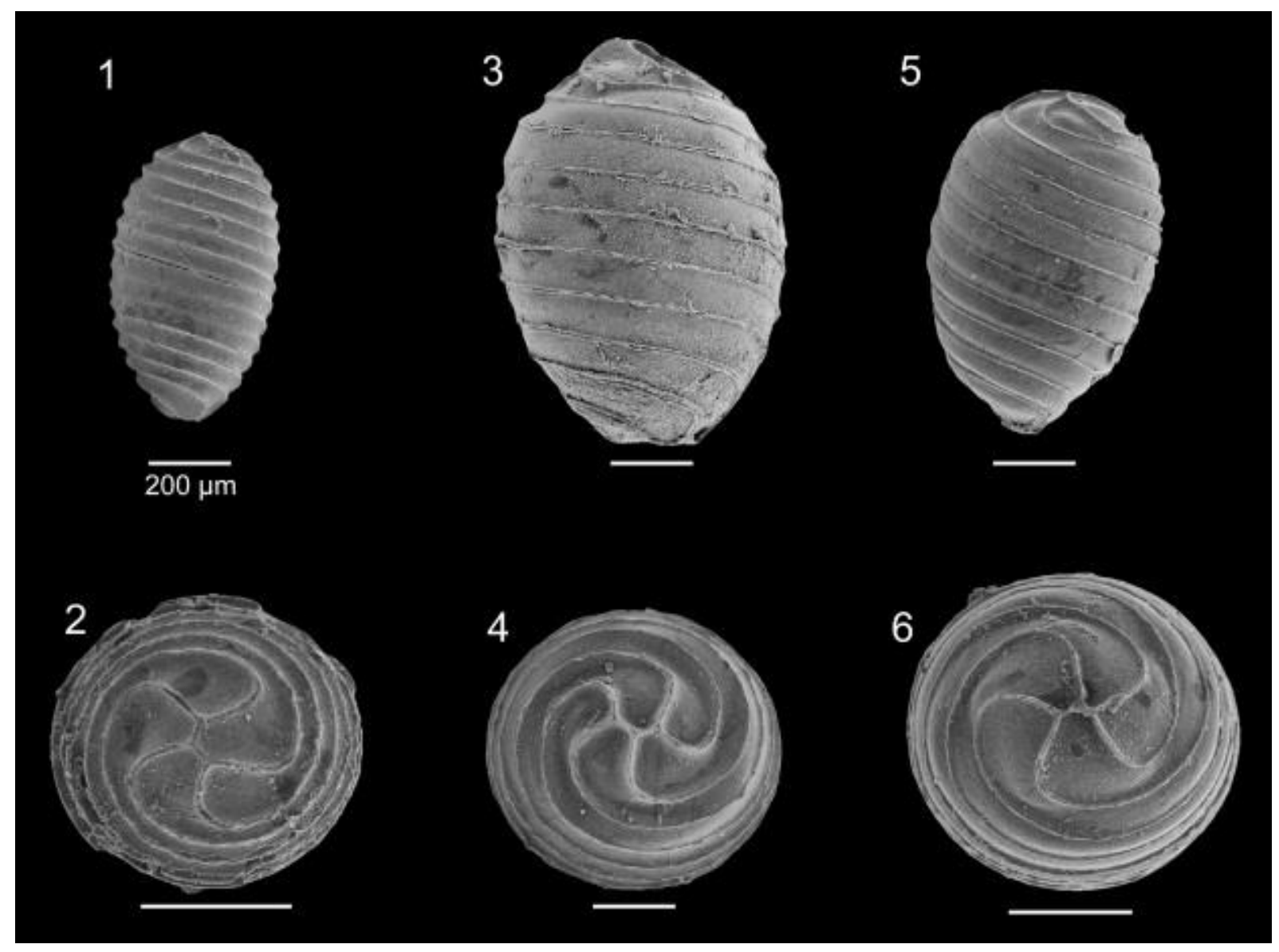

Fig. 5. SEM Lateral and apical views of Chara aspera (1 and 2), Chara hispida (3 and 4) and Chara globularis (5 and 6) gyrogonites. Scale bars are all $200 \mu \mathrm{m}$.

Facies show varying degrees of stem preservation and encrustation (Fig. 6 and Fig. 7B). Very well-preserved facies present large $(2-3 \mathrm{~cm})$ encrusted stem fragments, with 3D preservation of the cortical system (see Fig. 7B-1,-2). Well-preserved facies show smaller encrusted stem remnants and rare cortical system preservation (star shape, Fig. 7B-3). Poorly preserved facies consist of broken, highly compacted, encrusted stem remnants (Fig. 7B-4). Charophyte remains are rare and poorly preserved in palaeosols where they are interpreted as reworked material. A small number of gyrogonites are found in palustrine silts in a mixture of in situ and reworked material. While distal tufas contain a substantial amount of very well-preserved encrusted stems, proximal deposits reveal scarce, poorly preserved encrusted stems (Fig. 6). However, proximal pits reveal large amounts of gyrogonites and oospores, decreasing towards the distal area (Fig. 6). 


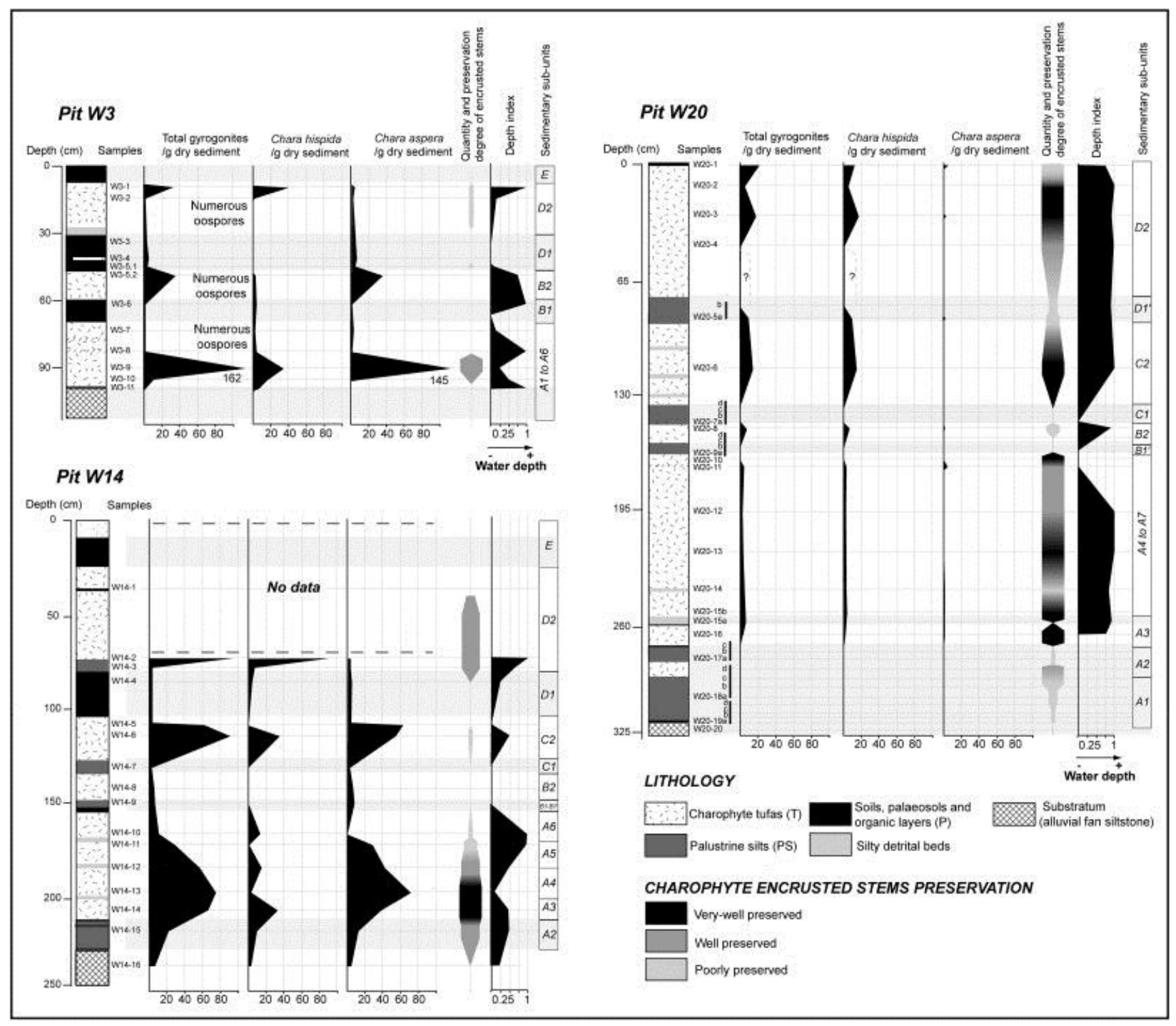

Fig. 6. Frequency and distribution of Chara species (gyrogonites) counted in proximal (W3), median (W14) and distal (W20) pits of the shore terrace of lake Afourgagh in correlation with simplified lithological columns and sedimentary sub-unit boundaries. Inferred water level index (corresponding to C. hispida gyrogonites/total amount of gyrogonites) and the encrusted charophyte stems preservation degree are also shown. 


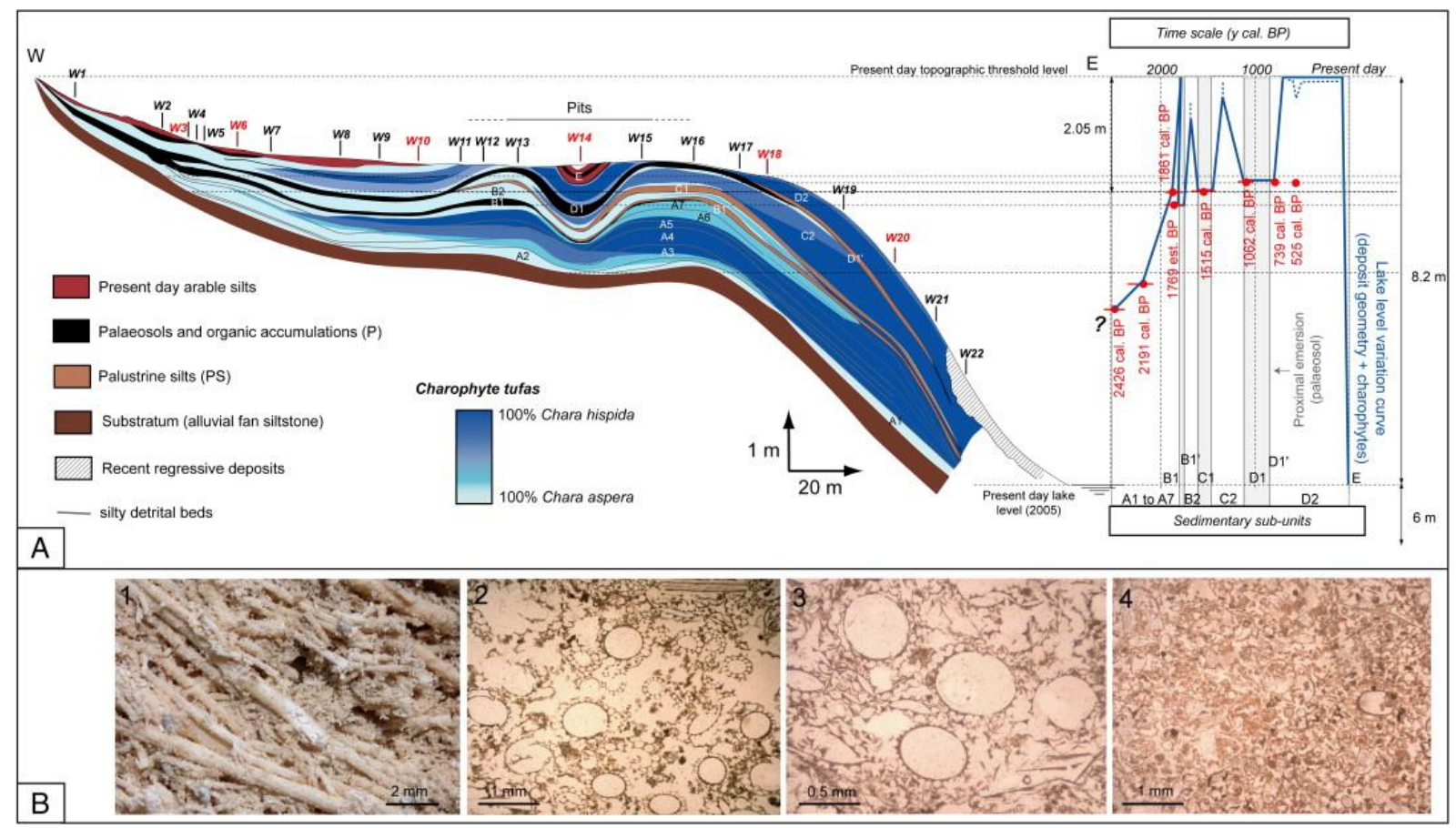

Fig. 7. A - Deposit geometry on the west transect of the Lake Afourgagh, facies, sedimentary sub-units, distribution of Chara hispida vs Chara aspera gyrogonites, lake level variation curve deduced from deposit geometry + charophyte distribution, and associated radiocarbon chronology. B - Examples of macro and microfacies: 1 - Macrofacies of very well-preserved charophyte tufa (pit W20); 2 - Microfacies of very well-preserved charophyte tufa presenting a large number of very well-preserved encrusted stems (sample W20-3); 3- Microfacies of well-preserved charophyte tufa enriched in star shaped encrusted stems (sample W20-15); 4 - Microfacies of poorly preserved charophyte tufa showing scattered encrusted stem fragments (sample W3-2).

Charophytes prefer undisturbed, clear, oxygenated water. They are among the first macrophytes to colonize a water body after major perturbations (Corillion,1957, Crawford, 1977 and Moore, 1986). All of the fossil species observed in Lake Afourgagh sediments have extant representatives serving as a reference for their ecological characteristics. C. aspera is typical of shallow water environments and can be found up to depths of about $6 \mathrm{~m}$ (Blindow and Schütte, 2007), with main occurrences between 0 and $4 \mathrm{~m}$ (Corillion,1957 and Krause, 1997). C. hispida can grow in water up to depths of about $10 \mathrm{~m}$, with main occurrences between $1 \mathrm{~m}$ and $7 \mathrm{~m}$ ( Corillion,1957 and Krause, 1997). Although rare in North Africa, $C$. hispida has been found in the karstic Lake Tigalmamine (Morocco), living at a depth of 2 to $9 \mathrm{~m}$ (Soulié-Märsche et al., 2008). This population provides a modern analogy for the ecological conditions of $C$. hispida in the Middle-Atlas Mountains.

\subsection{Species distribution}

The distribution of charophytes by species was recorded in detail in six pits (W3, W6, W10, W14, W18 and W20) and then deduced by extrapolation along the whole transect (Fig. 6 and Fig. 7). For each pit, a depth index was calculated using the ratio of $C$. hispida gyrogonites/total amount of gyrogonites. This takes into account the relative abundance of the two major species (C. aspera and C. hispida) and their ecological preferences in terms of bathymetry, in order to infer water level fluctuations (Fig. 7). 
Major observations can be made about species distribution and frequency at the various scales: (1) transect, (2) pit, and (3) charophyte tufa (sub-unit). Along the transect, the general distribution of gyrogonites shows abundant $C$. aspera in the proximal area, particularly from the palaeo-shoreline to pit W7, whereas the charophyte tufas reveal abundant $C$. hispida gyrogonites in the distal area ( Fig. 6 and Fig. 7). The median area of the transect displays variable gyrogonite amounts of each species (zone of species mixing). In a single pit, charophyte tufas display variable amounts of each species, indicating marked differences of depositional conditions during the last 2500 years. For instance, in pit W10, sub-unit B2 is dominated by $C$. aspera gyrogonites, while sub-unit D2 tufa exhibits high amounts of $C$. hispida gyrogonites (Fig. 7). Within a single sub-unit of tufa, the degree of preservation and the species type of charophyte remains are dependent on lake depth through time. For example, charophyte tufas at the base of the sub-units, set on palustrine silts or palaeosols (sub-units B1-B1', C1, D1-D1'), are generally poorly preserved, with gyrogonites and oospores of $C$. aspera (e.g. sample W14-2, Fig. 6 and Fig. 7). The median part of the tufa subunits can display large amounts of both gyrogonite species depending on its location along the transect, i.e. in relation to the depositional environment (depth, luminosity, dynamics, turbidity, etc.). Finally, the upper part of the tufa sub-units, situated immediately under palaeosols or palustrine silts, are dominated by $C$. aspera gyrogonites, even in the distal zone (e.g. sample W14-5, Fig. 6 and Fig. 7).

Along the transect (Fig. 7), at the base and top of units A, B, C, and D, the tufa sub-units are enriched in $C$. aspera gyrogonites from the palaeo-shoreline to the distal zone (pits W18W19). However, in unit A, sub-units A1 to A3 show quantities of $C$. aspera gyrogonites along most of the transect except in the distal zone (from pit W18 to pit W22). Sub-units A4 and $\mathrm{A} 5$ are enriched in $C$. aspera gyrogonites only in the very proximal zone, and in $C$. hispida gyrogonites in the distal zone. Sub-units A6 and A7 display a dominance of $C$. aspera gyrogonites. Sub-units B2 and C2 show a comparable distribution with the dominance of $C$. aspera gyrogonites in the proximal zone to the upper part of the distal zone (pits W18-W19). For the sub-unit D2 tufa, C. aspera gyrogonites are predominant in the proximal zone (palaeo-shoreline to W7) and C. hispida in median and distal areas (W7 to W22).

The depth index has higher values in tufas than in silty detrital layers and palustrine silts. The highest values, corresponding to high lake levels, are observed in the distal pits.

\section{Discussion}

The mass accumulation of charophyte remains within the tufas testifies to periods during the last 2500 years when large charophyte meadows occupied the shore terrace of Lake Afourgagh. Variations in the composition of charophyte species in the tufas, vertical in pits and horizontal along the transect, reveal particular responses of charophyte development to environmental (water level) changes. As mentioned above, the degree of stem preservation and encrustation varies from the proximal to the distal areas of the transect. The poorly preserved aspect of encrusted stems in the proximal area is the result of: (1) seasonal disturbances, with successive rise and fall of the water level, (2) long-standing emersion periods, i.e. wind, runoff erosion and pedogenesis processes combined with possible human activities such as agriculture and animal husbandry, (3) compaction. These factors are also responsible for the breaking or dehiscence of gyrogonites, inducing the presence of numerous damaged oospores in proximal tufas (Fig. 6, pit W3). 
The addition of geometry (Détriché et al., 2008), facies, and charophyte data have allowed a detailed reconstruction of lake level fluctuations over the last 2500 years (Fig. 7). Some facts are particularly valuable for interpreting the charophyte data.

Gyrogonites are considered as in situ deposits, as they generally correspond to autochthonous fossils in this kind of environment (Soulié-Märsche, 1991 and Soulié-Märsche et al., 2008). This is also inferred from the co-occurrence of very well-preserved encrusted stems (in life positions) and gyrogonites.

Charophyte meadows are essentially composed of Chara aspera and Chara hispida stands, with the thickest accumulations near pits W18-W19 (Fig. 7). Three parts can be distinguished in a single meadow, with a proximal belt containing only $C$. aspera, a distal belt with only $C$. hispida, and an intermediate belt where the two species occur together. This species-specific distribution is in line with data in the literature concerning the optimum depth for the development of $C$. aspera and $C$. hispida.

These data (e.g. Benkaddour, 1993 and Soulié-Märsche et al., 2008 for Lake Tigalmamine, Middle-Atlas Mountains, Morocco) indicate that $C$. aspera develops better in shallower environments than $C$. hispida. Consequently, the predominance of $C$. aspera gyrogonites is considered to be a "low lake level" indicator, and predominance of $C$. hispida gyrogonites a "high lake level" proxy.

Charophytes develop best in shallow water with good light penetration (Moore, 1986, Schwarz et al., 2002 and Blindow et al., 2003) and synthesize gyrogonites preferentially in shallow, disturbed water (Corillion, 1957 and Casanova, 1994). On the other hand, vegetative reproduction occurs mostly under deeper and unstressed conditions, as in the case of $C$. aspera and C. hispida (Corillion,1957 and Soulié-Märsche et al., 2008).

The proximal tufa (palaeo-shoreline to W7) enrichment in gyrogonites dominated by $C$. aspera is regulated by: (1) a shallow, permanent to semi-permanent water body, (2) good light penetration, but (3) seasonal variations of the water level leading to occasional turbid conditions. As a result, $C$. aspera develops in preference to $C$. hispida - which prefers deeper water - and the proximal part of the meadow synthesizes a large number of gyrogonites in response to hydrological stress. From W7 to W18, in the median part of the transect, the vertical and lateral changes in species distribution led to patterns of migration, with contractions and extensions of the charophyte belts over the last 2500 years. These changes clearly result from water level fluctuations and the gradual reduction of space over time as a consequence of sediment accumulation. In the distal area, deeper water and quiet conditions, as evidenced by the very well-preserved encrusted stems, favoured the development of $C$. hispida meadows. The lower frequency of $C$. hispida gyrogonites suggests the predominance of vegetative reproduction in this perennial part of the lake, with propagation through nodal bulbils.

The quantity of gyrogonites was observed to vary within a sub-unit of charophyte tufa, from base to top. For example, $C$. aspera gyrogonites are generally relatively abundant just below the palaeosol-palustrine silt facies of the proximal and distal areas (corresponding to subunits B1-B1', C1, D1-D1') because of the regression and subsequent establishment of this charophyte which prefers shallow water environments. The $C$. aspera belt migrated towards the new shallow water zone in distal areas during falling water levels in regressive episodes. By contrast, the $C$. hispida belt migrated towards the proximal area during transgressive 
events, as shown by the distribution of charophyte species in tufas of units A (sub-units A3 to A5) and D (which record the highest lake levels, Fig. 7). These events appear to repeat themselves to varying extents from one sequence to another. Proximal, poorly preserved charophyte tufas exhibit a high abundance of $C$. aspera gyrogonites, while distal, wellpreserved charophyte tufas display mostly $C$. hispida gyrogonites.

\subsection{Sequence 1 (2191 cal. BP-1769 BP est.)}

Sub-unit A1 is a typical palustrine environment with a succession of silty-clayey beds enriched in very well-preserved remnants of non-charophyte macrophyte stems, ostracods, molluscs and sponge spicules. Only a few poorly preserved encrusted stems of charophytes and $C$. aspera gyrogonites are found, indicating an environment that was not favourable to charophyte colonization. From lateral correlation of sub-unit A1, it can be estimated that the centre of the lake was $\sim 10.5 \mathrm{~m}$ deep at $2191 \mathrm{cal}$. BP. This resulted in the development of a large charophyte meadow, observed from pits W22 to W4, producing $C$. aspera gyrogonites between pit W4 and pit W18 and sparse $C$. hispida gyrogonites distally, testifying to a low lake level constrained by topography in proximal and median areas. The rapid rise of lake level, together with a shift from shallow agitated water to deeper and more stable conditions, allowed colonization by charophytes and the formation of the sub-unit A2 tufa. Charophytes are in fact among the first macrophytes to colonize a water body after major perturbations ( Corillion,1957, Crawford, 1977 and Moore, 1986). Maximal lateral expansion of an exclusively $C$. aspera gyrogonite zone suggests that the maximum fluctuation depth in $1861 \mathrm{cal}$. BP was $\sim 2.5 \mathrm{~m}$ and the depocenter $\sim 11.7 \mathrm{~m}$. During the deposition of sub-unit A3, the lake level continued to rise, reaching a depth of $\sim 12.5 \mathrm{~m}$, as shown by the fact that the charophyte meadow extended to the proximal area of the transect, with a westward migration of the C. aspera belt to the proximal zone (Fig. 8A). Sub-unit A4 records a highstand phase with the water level reaching the topographic threshold (lake depth of $\sim 14.5 \mathrm{~m}$ ) as the $C$. hispida belt migrated gradually to the proximal zone, as confirmed by the geometry of the facies in Unit A (Fig. 8B). The steady state of the lake environment and the greater water depth provided optimal development conditions for $C$. hispida. The lateral extent of sub-unit A5 is unknown (erosional hiatus), but its gyrogonite species content is the same as sub-unit A4, suggesting a comparable water depth and continuity of the highstand phase at the topographic threshold level. A prolonged highstand phase was favourable for the development of a $C$. hispida belt which extends from pit W7 to the base of sub-unit A6. The top part of sub-unit A6 and the whole of sub-unit A7 display exclusively $C$. aspera gyrogonites, inferring a fall of lake level with the migration of the $C$. aspera belt to the distal zone. The lateral extension of sub-unit A6 is also unknown but probably corresponds to a highstand, as in subunit A5 (Détriché et al., 2008). Sub-unit A7 exhibits the first indication of falling water level. Charophyte data show that the water level fell progressively and could have occurred as early as the deposit of A6 (Fig. 8C). A lowstand phase with proximal emersion is evidenced by the sub-unit B1 palaeosol (beginning of Sequence 2). 


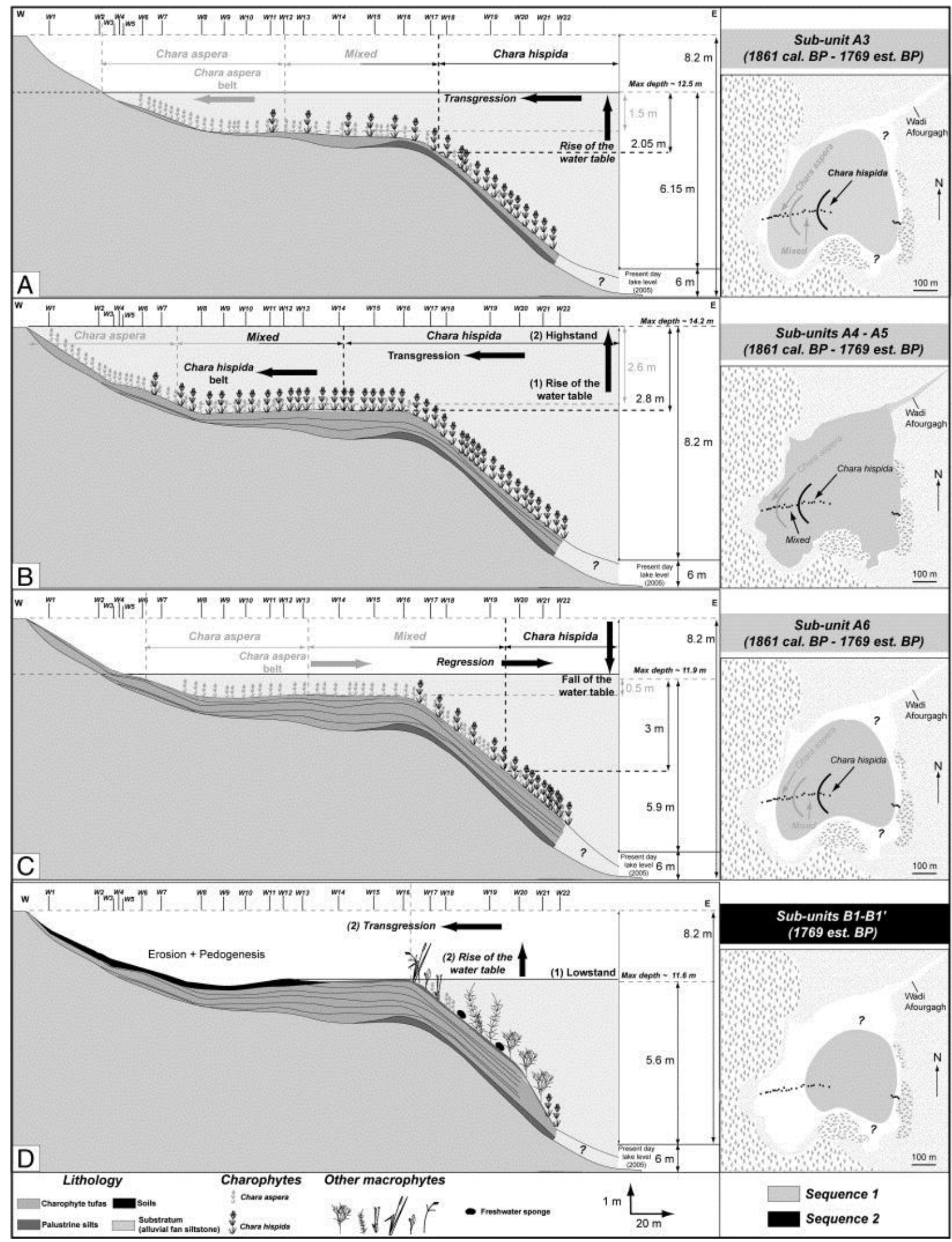

Fig. 8. Representative behaviour of the charophyte meadow evolution during a depositional sequence (example from S1 to S2). Evolution of the lake Afourgagh palaeobathymetry inferred from the relative frequency of Chara hispida vs Chara aspera gyrogonites. The migration of the charophyte meadow as a function of water depth is shown for four levels of sub-units A3 to A6 and B1-B1' corresponding to the transition from Sequence 1 to Sequence 2. 


\subsection{Sequence 2 (1769 BP est.-1515 cal. BP)}

A prolonged lowstand phase with proximal emersion induced palaeosol development from the palaeo-shoreline to pit W16, corresponding to sub-unit B1, at about $1769 \mathrm{BP}$ (Fig. 8D). The lateral facies transition to palustrine silts (sub-unit B1'), comparable to patterns described for sub-unit A1, testifies to a shallow and probably turbid proximal environment favourable for colonization by non-charophyte macrophytes. Charophytes were probably present near the centre of the shallow lake. The transgressive overlap of these silts on the palaeosol illustrates the change in palaeo-environmental conditions which increased sedimentation and preserved the non-charophyte macrophytes. As observed in Sequence 1, charophytes colonized the shore terrace progressively as the water level rose and more stable conditions returned, leading to the formation of the sub-unit B2 tufa. As in Sequence 1, C. aspera was the first species to colonize the area, as it can be observed distally just below the palustrine silts (Fig. 7). Even though the lateral extent of B2 is unknown, the distribution of charophyte species shows that the water level probably did not reach the topographic threshold level as it did in Sequence 1. In fact, $C$. aspera occurs exclusively from the palaeo-shoreline to pit $\mathrm{W} 15$ and $C$. hispida remains are found in the distal area as a consequence of a relatively low lake level. A fall of water level is illustrated by the abundance of $C$. aspera gyrogonites just under the sub-unit $\mathrm{C} 1$ palustrine silts, resulting from a migration of the belt to the distal area.

\subsection{Sequence 3 (1515 cal. BP-1062 cal. BP)}

Sub-unit C1 corresponds to palustrine silts, with no data available on its proximal continuation, but possibly inter-bedding with palaeosols at the lake margin. However, a lowstand phase at ca $1515 \mathrm{cal}$. BP is surmised because of the lowering of lake level clearly initiated at the end of Sequence 2. The facies characteristics and patterns in Sequence 3 are similar to those of Sequence 2 except for the lateral species distribution in the sub-unit C2 tufa. The formation of a charophyte tufa indicates a new rise of water level. C. aspera was once again the first species to colonize the environment once the water level had risen sufficiently. The continuing rise of the lake allowed the $C$. aspera and $C$. hispida belts to migrate to the proximal area until the $C$. hispida belt reached pit W13. The lateral extent of the $C$. hispida belt is wider than in the sub-unit B2 tufa, illustrating that the water level probably reached the topographic threshold limit. The uppermost portion of sub-unit $\mathrm{C} 2$ tufa shows a migration of the $C$. aspera belt towards the distal area, attesting to a subsequent fall in lake level.

\subsection{Sequence 4 (1062 cal. BP-present day)}

The fall of water level ended with a lowstand phase (lake depth of $\sim 12 \mathrm{~m}$ ) leading to an emersion of the proximal zone and to the subsequent development of a palaeosol corresponding to sub-unit D1. This is the most widespread palaeosol over the whole interval, as it reached the W18-W19 pits, providing evidence of a significant lowstand event. Radiocarbon data acquired from the base and top of sub-unit D1 (pit W3, Table 2) reveal ages of 1050 and 739 cal. BP respectively, showing the long duration of this phase. The facies succession of Sequence 4 resembles the other sequences. Sub-unit D1' palustrine silt (dated 1062 cal. BP) is overlain by sub-unit D1 palaeosol. A fall in water level is evidenced in the upper portion of sub-unit D2 by the predominant return of $C$. aspera to the proximal lake area followed by the migration of the belt towards the distal area. Development of the Unit $\mathrm{E}$ palaeosol and the fall in lake level occurred in response to human activities. 
From charophyte remains and the geometry of facies through time, water level fluctuations can be estimated to be $\sim 2.5 \mathrm{~m}$ below the topographic threshold level during the last 2500 years. The maximum lake depth fluctuated from $\sim 14.5 \mathrm{~m}$ to $\sim 12 \mathrm{~m}$ on a centennial scale, but it is possible that seasonal fluctuations were responsible for temporarily lower lake levels. During the last thirty years, a rapid $8.2 \mathrm{~m}$ fall of water level is principally the consequence of human activities, notably the development of irrigated arboriculture (Gamez et al., 2001 and Chillasse et al., 2001).

\section{Conclusion}

Species distribution, together with the degree of preservation of charophyte remains such as gyrogonites and encrusted stems, allowed changes in lake level to be reconstructed. For example, the lake registered major lowstands with subsequent proximal palaeosol formation between 2426 and $2191 \mathrm{cal}$. BP, at $1861 \mathrm{cal}$. BP, at $1769 \mathrm{BP}$, at $1515 \mathrm{cal}$. BP, and between 1050 and $739 \mathrm{cal}$. BP. The amplitude of the water level fluctuations directly affected the position of the charophyte meadow belts through time. As the water depth changed, the meadows moved laterally, perpendicular to the shore terrace, according to the most favourable conditions. This is illustrated by the proximal migration of the $C$. aspera and $C$. hispida belts during rising lake levels and distal migration when the level fell. Charophyte studies in palaeolimnological reconstructions are important not only as a complementary tool, but as a useful proxy for identifying past lake levels and depositional environments.

\section{Acknowledgements}

This work was supported by the "Action Intégrée" MA 01/10 programme (François Rabelais University, Tours, France/Sidi Mohamed Ben Abdellah University, Fez, Morocco) and the CNRS-ECLIPSE project: "Impact anthropique sur l'érosion des sols et la sédimentation dans les zones humides associées durant l'Holocène" in 2005 and 2006-2007. We thank members of the Dhar Marhaz Fes geology department for logistical support. Discussion with P. Anadón was much appreciated and helpful. We thank J.P. Bakyono of UMR CNRS 6113 ISTO-Tours and M. Fontugne of the UMR CNRS- CEA 1572, Laboratoire des Sciences du Climat et de l'Environnement (LSCE), for laboratory support and advice. Sincere thanks to E. GierlowskiKordesch and anonymous reviewers for their helpful review of the manuscript.

\section{References}

M. Amyay, M. Laaouane, B. Akdim

La pression anthropique sur les ressources en eau souterraine dans le Moyen-Atlas. Exemple de la dépression d'Afourgagh

Mosella, XXV (3-4) (2001), pp. 341-351

P. Anadón, F. Burjachs, M. Martin, J. Rodriguez-Lázaro, F. Robles, R. Utrilla, A. Vasquez

Paleoenvironmental evolution of the Pliocene Villarroya Lake, Morthern Spain. A multidisciplinary approach

Sediment. Geol., 148 (2002), pp. 9-27

Baali, A., 1998. Genèse et évolution au Plio-Quaternaire de deux bassins intramontagneux en domaine carbonaté méditerranéen. Les bassins versants des dayets Afourgagh et Agoulmam (Moyen-Atlas, Maroc). Thèse 3ème Cycle, Rabat, Morocco. 326 pp. 
Benkaddour, A., 1993. Changements hydrologiques et climatiques dans le Moyen-Atlas marocain: chronologie, minéralogie, géochimie isotopique et élémentaire des sédiments lacustres de Tigalmamine. Thèse 3ème Cycle, Université Paris XI, France. 156 pp.

A. Bentayeb, C. Leclerc

Le Moyen-Atlas, le causse Moyen-Atlasique. In: editions du service géologique du Maroc, Ressources en eau du Maroc, domaines atlasique et sud-atlasique

Notes Mém. Serv. Géol. Maroc, 231 (1977), pp. 37-66

I. Blindow, M. Schütte

Elongation and mat formation of Chara aspera under different light and salinity conditions

Hydrobiologia, 584 (2007), pp. 69-76

I. Blindow, J. Dietrich, N. Möllmann, H. Schubert

Growth, photosynthesis and fertility of Chara aspera under different light and salinity conditions

Aquat. Bot., 76 (2003), pp. 213-234

M.T. Casanova

Vegetative and reproductive responses of charophytes to water-level fluctuations in permanent and temporary wetlands in Australia

Aust. J. Mar. Freshw. Res., 45 (1994), pp. 1409-1419

Charrière, A., 1990. Héritage hercynien et évolution géodynamique alpine d'une chaîne intracontinentale: le Moyen Atlas au Sud-Est de Fès (Maroc). Thèse doct. Etat, Toulouse III, France. 589 pp.

R. Cheddadi, H.F. Lamb, J. Guiot, S. Van der Kaars

Holocene climatic change in Morocco: a quantitative reconstruction from pollen data

Clim. Dyn., 14 (1998), pp. 883-890

L. Chillasse, M. Dakki, M. Abbassi

Valeurs et fonctions écologiques des zones humides du Moyen Atlas

Humed. Mediterr., 1 (2001), pp. 139-146

H. Coops, R.W. Doef

Submerged vegetation development in two shallow, eutrophic lakes

Hydrobiologia, 340 (1996), pp. 115-120

R. Corillion

Les Charophycées de France et de l'Europe occidentale

Bull. Soc. Sci. Bretagne, 32 (1957) (hors-série 1-2, 499 pp.)

A. Crawford

Chemical, physical and biological change associated to Chara succession in farm ponds

Hydrobiologia, 55 (1977), pp. 73-77 
Détriché, S., 2007. Evolution d'un système lacustre karstique au cours de la période historique d'après l'étude des archives sédimentaires: la dayet Afourgagh (Moyen-Atlas, Maroc). Thèse de $3^{\text {ème }}$ cycle, Université François Rabelais de Tours, Tours, France, 372 pp.

S. Détriché, J.-G. Bréhéret, H. Zarki, L. Karrat, J.-J. Macaire, M. Fontugne Late Holocene palaeohydrology of lake Afourgagh (Middle-Atlas, Morocco) from deposit geometry and facies

Bull. Soc. Géol. Fr., 179 (2008), pp. 41-50

M. Djamali, I. Soulié-Märsche, D. Esu, E. Gliozzi, R. Okhravi

Palaeoenvironment of a Late Quaternary lacustrine-palustrine carbonate complex: Zarand Basin, Saveh, central Iran

Palaeogeogr. Palaeoclimatol. Palaeoecol., 237 (2006), pp. 315-334

N. Elkhiati, I. Soulié-Märsche, P. Gemayel, R. Flower, M. Ramdani

Recent environmental changes at Sidi Bou Rhaba Lake (Morocco) inferred from fossil Charophyte gyrogonites

Cryptogam., Algol., 25 (2004), pp. 175-188

H. Fan, F. Gasse, A. Huc, L. Yuanfang, A. Siffeddine, I. Soulié-Märsche

Holocene environmental changes in Bangong Co basin (Western Tibet). Part 3:

biogenic remains

Palaeogeogr. Palaeoclimatol. Palaeoecol., 120 (1996), pp. 65-68

G. Feldmann

Les Charophycées marocaines

Bull. Soc. Sci. Nat. Phys. Maroc, 33 (1953), pp. 13-22

R.J. Flower, I.D.L. Foster

Climatic implications of recent changes in lake level at Lake Azigza (Morocco)

Bull. Soc. Géol. Fr., 163 (1992), pp. 91-96

R.J. Flower, A.C. Stevenson, J.A. Dearing, I.D.L. Foster, A. Airey, B. Rippey, J.P.F. Wilson, P.G. Appleby

Catchment disturbance inferred from paleolimnological studies of three contrasted sub-humid environments in Morocco

J. Paleolimnol., 1 (1989), pp. 293-322

P. Gamez, J.P. Fizaine, D. Mansuy, J. Scapoli

La dayat Afourgagh: un exemple de surexploitation des eaux souterraines (MoyenAtlas septentrional, Maroc)

Mosella, XXV (3-4) (2001), pp. 217-226

A. García

Charophyta: their use in paleolimnology

J. Paleolimnol., 10 (1994), pp. 43-52

A. García

Quaternary charophytes from Salina del Bebedero, Argentina: their relation with extant taxa and palaeolimnological significance

J. Paleolimnol., 21 (1999), pp. 307-323 
A. García, A.R. Chivas

Diversity and ecology of extant and Quaternary Australian charophytes (Charales)

Cryptogam., Algol., 27 (2006), pp. 323-340

H. Horn af Rantzien

Morphological terminology relating to female Charophyte and fructifications

Bot. Not., 109 (1956), pp. 212-259

H. Horn af Rantzien

Recent charophyte fructifications and their relations to fossil charophytes gyrogonites

Ark. Bot. Ser., 4 (1959), pp. 165-332

A. Kohler, H. Vollrath, E. Beisl

Zur Verbreitung, Vergesellschaftung und Ökologie der Gefäss-Makrophyten in Fliessgewässer Moosach (Münchener Ebene)

Arch. Hydrobiol., 69 (1971), pp. 333-365

Krause, W., 1997. Charales (Charophyceae). Süsswasserflora von Mitteleuropa Bd. 18, $202 \mathrm{pp}$.

S. Kröpelin, I. Soulié-Märsche

Charophyte remains from Wadi Howar as evidence for deep mid-Holocene freshwater lakes in Eastern Sahara (NW Sudan)

Quat. Res., 36 (1991), pp. 210-223

P.J. Lamb, R.A. Peppler

West Africa, Chapter 5

M.H. Glantz, R.W. Katz, N. Nicholls (Eds.), Teleconnections: Linkages between ENSO, Worldwide Climate Anomalies, and Societal Impacts, Cambridge

University Press (1991), pp. 121-189

H.F. Lamb, S. Van Der Kaars

Vegetational response to Holocene climatic change: pollen and palaeolimnological data from the Middle Atlas, Morocco

Holocene, 5 (1995), pp. 400-408

H.F. Lamb, U. Eicher, V.R. Switsur

An 18000-year record of vegetation, lake-level and climatic change from

Tigalmamine, Middle-Atlas, Morocco

J. Biogeogr., 16 (1989), pp. 65-74

H.F. Lamb, F. Damblo, R.W. Maxted

Human impact on the vegetation of the Middle Atlas, Morocco, during the last 5000 years

J. Biogeogr., 18 (1991), pp. 519-532

H.F. Lamb, F. Gasse, A. Benkaddour, N. El Hamouti, S. Van Der Kaars, W.T. Perkins, N.J.

Pearce, C.N. Roberts 
Relation between century-scale Holocene arid intervals in tropical and temperate zones

Nature, 373 (1995), pp. 134-137

H.F. Lamb, N. Roberts, M. Leng, P. Barker, A. Benkaddour, S. Van der Kaars

Lake evolution in a semi-arid mountain environment: responses to catchment change and hydroclimatic variation

J. Paleolimnol., 21 (1999), pp. 325-343

M. Martin

Notes Mém. Serv. Géol. Maroc, 258 (1981) (445pp.)

J.A. Moore

Charophytes of Great-Britain and IrelandBSBI publications (1986) 144 pp.

N.C. Morgan

An ecological survey of standing waters in North West Africa: III. Site descriptions for Morocco

Biol. Conserv., 24 (1982), pp. 161-182

B. Rippey

Sedimentary record of rainfall variations in a sub-humid lake

Nature, 296 (1982), pp. 434-436

M. Scheffer, S.H. Hosper, M.-L. Meijer, B. Moss, E. Jeppesen

Alternative equilibria in shallow lakes

Trends Evol. Ecol., 8 (1993), pp. 275-279

A.M. Schwarz, M. De Winton, I. Hawes

Species-specific depth zonation in New-Zealand charophytes as a function of light availability

Aquat. Bot., 72 (2002), pp. 209-217

Soulié-Märsche, I., 1989. Etude comparée de gyrogonytes de Charophytes actuelles et fossiles et phylogénie des genres actuels. Thèse ès-Sciences, Université de Montpellier, 1979, revised edition. Millau, France, Imprimerie des Tilleuls.

I. Soulié-Märsche

Charophytes as lacustrine biomarkers during the Quaternary in North Africa

J. Afr. Earth Sci., 12 (1991), pp. 341-351

I. Soulié-Märsche

Apport des charophytes fossiles à la recherche de changements climatiques abrupts Bull. Soc. Géol. Fr., 164 (1993), pp. 123-130

I. Soulié-Märsche

Charophytes, indicators for low salinity phases in North African sebkhet

J. Afr. Earth Sci., 51 (2008), pp. 69-76

I. Soulié-Märsche, M. Benammi, P. Gemayel 
Biogeography of living and fossil Nitellopsis (Charophyta) in relationship to new finds from Morocco

J. Biogeogr., 29 (2002), pp. 1703-1711

I. Soulié-Märsche, A. Benkaddour, N. El Khiati, P. Gemayel, M. Ramdani

Charophytes, indicateurs de paléobathymétrie du lac Tigalmamine (Moyen-Atlas, Maroc)

Geobios, 41 (2008), pp. 435-444

M. Stuiver, P.J. Reimer

Extended C data and revised Calib 3.0 age calibration program

Radiocarbon, 35 (1993), pp. 215-230

M. Stuiver, P.J. Reimer, E. Bard, J.W. Beck, G.S. Burr, K.A. Hughen, B. Kromer, G. Mc Cormac, J. Van Der Plicht, M. Spurk

INTCAL98 radiocarbon age calibration, 24000-0 cal BP

Radiocarbon, 40 (1998), pp. 1041-1083

H. Tappan

Charophytes

H. Tappan (Ed.), The Paleobiology of Plant Protists, Freeman and Co, San

Francisco (1980), pp. 913-963

B.S. Vaidya

Study of some environmental factors affecting the occurrence of charophytes in Western India

Hydrobiologia, 29 (1966), pp. 256-262 